\title{
Donella H. "Dana" Meadows: a Designer of Systems for Advancing Quality of Life (1941-2001)
}

\author{
Richard J. Estes ${ }^{1}$
}

Published online: 20 February 2017

(C) Springer Science+Business Media Dordrecht and The International Society for Quality-of-Life Studies (ISQOLS) 2017

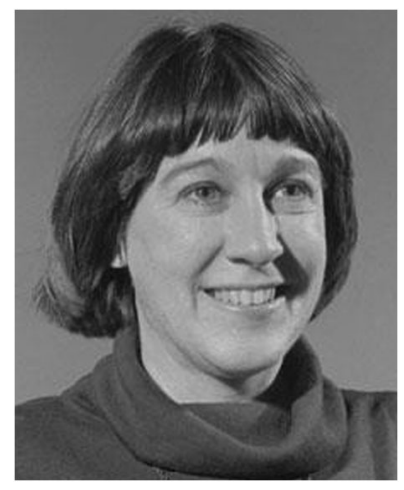

A few truly remarkable people are born each century whose life work add richness and texture to the lives of others. Donella "Dana" Meadows was one of those persons. Born in Elgin, Illinois, USA, she was educated in the physical sciences, receiving a B.A. in chemistry from Carleton College in 1963, and a Ph.D. in biophysics from Harvard in 1968. After a year-long trip from England to Sri Lanka and back, she became a research fellow at MIT, as a member of a team in the department created by Jay W. Forrester (World Dynamics, 1971), the inventor of system dynamics as well as the principle of magnetic data storage for computers. She taught at Dartmouth College for 29 years, beginning in 1972.

During her years at Dartmouth, and as director of the Donella Meadows Institute located in Norwich VT, Dana authored and co-authored a series of books on the "global

Richard J. Estes

restes@sp2.upenn.edu

1 University of Pennsylvania, School of Social Policy \& Practice, Philadelphia, PA, USA 
problematique" that engaged the entirety of humanity in pondering the nearterm prospects of quality of life and wellbeing: The Limits to Growth (1972); Toward Global Equilibrium: Collected Papers (1973); The Electronic Oracle: Computer Models and Social Decisions (1985); Global Citizen (1991); Limits to Growth-The 30 year Update (2004). Though often alarmist in tone, particularly with respect to assaults on the physical environment, Meadows always concluded with an agenda for action that people working at all levels of political organization could engage in to bring about a more positive future. The research institute and think tank that was established in her name, continues in the same tradition as that set by Dana Meadows in enjoining "fellow travelers" to unite in bringing about a more positive and optimistic future for all of humanity.

For her pioneering work in social modeling with a particular emphasis on the physical environment, Meadows was honored as a Pew Scholar isn Conservation and Environment (1991). She received the Walter C. Paine Science Education Award in 1990. Posthumously, she received the John H. Chafee Excellence in Environmental Affairs Award for 2001, presented by the Conservation Law Foundation.

Meadows wrote a weekly column called "The Global Citizen," commenting on world events from a systems point of view. Many of these columns were compiled and published in a series of books (Meadows 1991). Her work is recognized as a formative influence on hundreds of other academic studies, government policy initiatives, and international agreements.

Meadows was a long-time member of the United States Association for the Club of Rome, which instituted an award in her memory: "The US Association for the Club of Rome Donella Meadows Award in Sustainable Global Actions." This award is given to an outstanding individual who has created actions in a global framework toward the sustainability goals Meadows expressed in her writings.

In 2001, Meadows sadly passed away from a bacterial infection. Reflecting on her own life as a scholar and as a "fellow traveler" seeking improved quality of life for others, Meadows wrote:

My writing is a search for Truth.

It comes out of love.

It empowers; it does not judge

or accuse or rob anyone of

dignity or respect.

It is clear and precise.

The passage of my words through

the minds of others leaves them 
more open, more thoughtful,

compassionate, committed to

Quality.

Every one of my readers is the Key

to the Workability of the Planet.

I give in my writing of myself

and my struggles unstintingly;

it is all I have to give; the

" $I "$ of it is unimportant; it is

the universal humanness that

is important.

I write to ennoble others, not myself.

Donella Meadows Institute.

January 26th, 2001.

\section{References}

Meadows, D. H. (1991). Global Citizen. Washington DC: Island Press. 